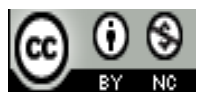

Jurnal Pendidikan IPS Indonesia is licensed under

A Creative Commons Attribution-Non Commercial 4.0 International License

\title{
FUCNTIONS OF CUSTOMARY LAW IN MANAGING WATER MANAGEMENT WITHIN FARMERS' ORGANIZATION: Case of Subak Kedua, Denpasar City, Bali Province, Indonesia
}

\author{
Dr. Putu Dyatmikawati, SH.M.Hum ${ }^{1)}$ \\ ${ }^{1)}$ Dwijendra University-Indonesia \\ E-mail: puhmika.dwijendrabali@gmail.com
}

\begin{abstract}
Irrigation water management in Bali province, Indonesia has been well known due to the existence of traditional irrigation system, called subak. Subak is not only an institution in agriculture, but also as a part of Bali's local wisdom. The philosophy of the subak system is Tri Hita Karana (three causes of happiness) which a basis for subak to manage irrigation and farming activities. The objective of this study is to describe the subak as organization and functions of customary law in sustaining the activities on farming and irrigation in subak system. The results of study point out that subak as an organization employs traditional management to members, particularly in irrigation and rice farming activities. In order to manage these activities, subak has established customary law based on the traditions happened in the community where subak is located and based on the Tri Hita Karana. Thus subak's customary law is specific location in nature. Therefore, the main contents of customary law concerning the parhyangan (relationship between farmers and God), pawongan (relationship among farmers) and and palemahan (relationship between farmers and environment). Applying Tri Hita Karana, subak ensures to achieve the harmony among the members and management board and make sustainable irrigation system.
\end{abstract}

Keywords: Customary Law, Tri Hita Karana, Subak, Harmony, and Sustainable

\section{INTRODUCTION}

Indonesia constitutes agrarian state due to most of the population has still dependent on the agricultural sector for their life. Roles of agricultural sector in economic development are (i) providing food for the people; (ii) creating an employment; (iii) supporting raw material to upstream agro-industry; (iv) consuming products produced by upstream agro-industry; and (v) providing additional revenue of the state as producing the export products. One of the agricultural commodities is rice which is becoming a staple food for Indonesian. The growth of population and food (rice) should be in balance in order to avoid the deficit of rice. Indonesia is a country that has imported rice from other countries, like Thailand, Vietnam, China and others.

Responding to this condition, rice farming has been continued to improve not only productivity and quality but also on rice business management. Presently, government has made acceleration on increasing productivity of rice through providing irrigation infrastructure, such as weir, irrigation canal and its operation and maintenance. Irrigation water management in Bali province as one of the provinces in Indonesia has been well known due to the existence of traditional irrigation system, called subak established since more than thousand years ago (Lansing, [1]; Pitana and Setiawan) [2]. The existence of local knowledge and local wisdom in Bali have still significantly important in ordering the social interaction among the people, including farmers. 
Rice farmers in Bali are being member of subak as traditional irrigation system or organization. This organization employs traditional management to members, particularly in irrigation and rice farming activities. In order to manage these activities, subak has established customary law based on the traditions happened in the community where subak is located. Thus subak's customary law is specific location in nature (Ndulo) [3] mentions that customary law is the indigenous law of the various ethnic groups having sources in the practices and customs of the people. The objective of this study is to describe the subak as organization and functions of customary law in sustaining the activities on farming and irrigation in subak system. The study was conducted through making descriptive analysis of the relevant studies conducted in Bali relating to the objectives of the study.

\section{DISCUSSIONS}

\section{Subak as traditional irrigation system}

The Water is one of the most important natural resource that is being used for agricultural and non-agricultural sectors. Nowadays, scarcity and competition of water have increasingly happened including in Indonesia. In Bali province, for instance, these frequently make conflicts among the users, such as subak, private sectors (for tourism and industry), and government (for domestic water), particularly along the water source such as river. Subak as an organization that regulates the distribution of water in the rice is one of Bali's cultural heritage that has been recognized worldwide. Subak irrigation system in Bali has been known since more than thousands ago (Roth and Sedana, [4]; Sedana, et al) [5]. In the past, the kings (monarchy) involved in subak system by allowing farmers' group to construct temporary dams on the rivers to irrigate the existence dry land. Even, the Monarchy gave freely some land tax for the farmers. In the period of the Dutch administration, the head of subak was instructed to collect land tax from the farmers (subak members). It is worthy to note that subak has specific activity--ritual ceremonies which might not be found in other irrigation systems in Indonesia (even in the world).

The existence of subak is not similar with the village even though the members are similar. Subak's boundaries is based on the hydrological border, but the village is based on the administrative one. In some cases, the areas of subaks are passing the areas of some villages. It means that the areas of subaks are located within more than one village. However, there is also some subaks located within one village. It is dependent on the areas of subaks, and also area of village.

Subak is not only an institution in agriculture, but also as a part of Bali's local wisdom about human society and its relationship with the environment. Subak is a customary law community that has the characteristics of socioreligious-agriculture, which represents farmers' associations that manage an irrigation system in paddy fields. The philosophy of the subak system is Tri Hita Karana (three causes of happiness) concept based on the harmony among the three. Tri Hita Karana is a universal concept of harmony and togetherness (Windia) [6]. In daily activity, subak is managed by the chairman (called pekaseh) assisted by secretary (called penyarikan), and treasurer (called petengen) and general assistant (called saye). The chairman of subak democratically is elected by all members of subak in line with the customary law. Generally, the period of being chairman is five years and he might be able to elect any more, dependent on the members. Customary law of subak define the prerequisites of chairman, such as honest, knows well about irrigation system.

In the subak which has large area, there might be divided into smaller area (subsubak, called tempek) and chaired by a chairman of subsubak, called kelihan tempek. He assisted chairman of subak at the level of sub-subak, such as coordinating members to conduct the activities within subsubak. Coordination between chairman of subak and subsubak is also arranged in the customary law.

Pekaseh coordinates the activities relating to farming and irrigation and ritual ceremonies. In 
term of farming, pekaseh always invites management board and members in the meeting before planting seasons to define seed variety, planting schedule, the use of agro-inputs and others. In the irrigation aspect, pekaseh coordinates the water distribution among farmers, and or subsubak, including the water borrowing system, especially during dry season. The activities of recording including inventory of assets in subak are responsible by the secretary. Menawhile, the treasurer has fully responsibility of keeping financial aspect of subak. The treasurer and secretary must be responsible to the chairman of subak.

\section{Contents and functions of customary law}

Principally, the contents of customary law of subak including, such Subak of Kedua in Denpasar city are relating to parhyangan (relationship with the God); pawongan (relationship with human being); and palemahan (relationship with environment) as its philosophy namely Tri Hita Karana (THK). Tri Hita Karana is a basic concept that has been applied in the Balinese people life including subak since a long time ago to sustain irrigation and rice farming (Nopitasari, et al, [7]; Sriarta, et al) [8] Concept of THK has various excellences and universal relating to sustainable developments and environments (Sutawan [9]; Windia, [10]; Agung, [11], and Wesnawa) [12].

Parhyangan relates to Hindu religion, in which it is physically show by the building of temples within subak system (Windia, et.al.,) [6]. Generally, there are three levels of temple as a place for farmers (subak's members) to worship for the God. These are at the individual level, subak level and inter-subaks level. At the individual temple, each farmer has a small temple constructed at the inlet (small of irrigation division structure). Farmer has a belief that the availability of irrigation water in the inlet is created by the God. Therefore, each farmer must conduct ritual ceremony at this temple for every rice farming activities. The ritual ceremonies of farmers are strongly concerned to the stages of rice farming. In the land preparation, for instance, farmers conduct ritual ceremony at the temple and thus followed by the ritual ceremonies for seedlings, transplanting until harvesting.

At the subak level, the ritual ceremonies are performed in some temples owned by subak, such as temple constructed within the area of subak, called temple of bedugul, temple constructed near the weir, called temple of ulun empelan. The chairman of subak coordinates the performance of ritual ceremonies at the subak level started from preparation until completion of performance. Under the customary law, preparation of this ritual ceremony is assisted by the wives of farmers for making offering that is very complex offering. At the Bedugul temple, ritual ceremonies are conducted after the rice is "pregnant" (about two months after transplanting). Subak always chose the best day in line with the Hindu calendar and agreed by the members. At the ulun empelan temple, the subak has ritual ceremony for symbolically fetching irrigation water from the weir (at the river).

At the inter-subaks temple level, some subak s would have similar ritual ceremony at the same temple. These subaks historically have similar traditional life and have a temple which is worshiped together since a long time ago. Owing to change of the hydrological border of subak, they must be separated only in farming activity but still together in performing ritual ceremony at the similar temple. Also, all subaks which have belief that their irrigation water coming from the lake, they will go the temple constructed in lake (in Bali, there are four lakes).

Concerning pawongan aspect, customary law of subak orders the management and organization of subak to attain the harmony in the farming and irrigation activities. Based on the customary law, subak has monthly meeting (1 month equals to 35 days in line with Hindu calendar). Every month, all members of subak must attend the regular meeting and this is without any announcement. Incidental meeting, however, pekaseh (and kelihan tempek) must inform members to attend the meeting. In the customary laws, there is a fine or sanction for those who do not attend the meeting. In subak system, it is stated in the customary law 
that meetings of subak are divided into two kinds, namely management boards meeting and assembly meeting (attended by all members). Aside from meeting, pekaseh also coordinates the contribution of members if there is an event that would be conducted. The kind and amount of contribution are agreed by all members through the meeting. Decision making process in subak system should be based on consensus and democratic as cited in the customary law.

The harmony among the farmers and management board of subak is also shown in the process of water borrowing. Subak's customary law defines that farmers are allowed to borrow water from the other farmers with the agreement and approval of management board. During dry season, individual farmer often borrows water to irrigate his farm land. The process is very simple as defined in the customary law. The simplicity of this process is addressed to avoid farmer stealing water due the complexity of water borrowing process, while he needs irrigation water immediately. Water borrowing is also happened between the sub-subak (tempek). In this case, the chairmen of subsubaks will have discussion about water borrowing relating to how many hours, when will be borrowed and who will take an action on the process. The agreement between the two then is brought to the chairman of subak (pekaseh) to be acknowledged. Conflict management is under the consensus among the subak as cited in the customary law. If a farmer is known stealing water, he would be fined in line with the customary law. It defines that fines of stealing water at the primary canal, secondary canal, and tertiary canal are different. The amount of sanction/fine would be decided in the meeting of subak. In term of palemahan (environment), customary law of subak has define how to keep and maintain environment, such as water, soil, irrigation facilities, and erosion. Farmers are obliged to make clear on their borders of rice field and the canal in order to avoid conflict among them. Farmers are not allowed to catch fish on the canal by using chemical material. For rice farming, subak also forbids farmer to use more chemical fertilizer and pesticide. It must be wisely used fertilizers and pesticides and must follow the recommendation from the government. As usual, farmers will clean the canals and dikes before planting season to ensure that water could flow well. THK implicitly has messages that natural resources should be managed wisely and always thank the God and ensure to have harmony among the farmers in the irrigation and farming activities. This is indicated that local wisdom values application on THK of subak has proved that it is considered as the unique and the world's most effective local irrigation and farming management (Lansing) [13].

Customary law of subak could secure the sustainability of water management at the source level (river) and irrigation facilities due to there is internal regulations ordering members to conduct. One of important things in customary law of subak is a social sanction. This sanction makes farmers are afraid of doing a wrong thing which break a rule. The customary law also defines that if someone break the rule and make harmful for the entity of subak, he would be heavily fined, such as blocking inlet on the canal to stop irrigating water to him.

\section{CONCLUSION}

Subak is not only an institution in agriculture, but also as a part of Bali's local wisdom about human society and its relationship with the environment. The philosophy of the subak system is Tri Hita Karana (three causes of happiness). As traditional irrigation system, subak has customary law to manage the activities relating to farming and irrigation based on the Tri Hita Karana. Therefore, the main contents of customary law are parhyangan (relationship between farmers and God), pawongan (relationship among farmers) and and palemahan (relationship between farmers and environment). This organization employs traditional management to members, particularly in irrigation and rice farming activities. In order to manage these activities, subak has established customary law based on the traditions happened in the community where subak is located. Thus subak's customary law is specific location in nature. 


\section{REFERENCES}

J.S.Lansing, Perfect order recognizing complexity in Bali. Princeton and Oxford: Princeton University Press, 2006.

G.Pitana, and G.A.P.Setiawan, Pariwisata sebagai Wahana Pelestarian Subak, dan Budaya Subak Sebagai Modal Dasar dalam Pariwisata. Jurnal Kajian Bali Volume 03, Nomor 02, Oktober 2013. Pp:159-160, 2013.

M. Ndulo, M, African Customary Law, Customs, and Women's Rights. Indiana Journal of Global Legal Studies 18:1.pp. 88-120, 2011.

G. Sedana, and W. Windia,"Social capital on agribusiness development in Subak Guama, Tabanan Regency, Bali”, Journal of Social Science, Vol. 35 No.2, 2012, Chulalongkorn Univ., Sosial Reseach Institute (CUSRI), 2012.

G. Sedana, et.all, Strenghtening Sosial Capital for Agricultural Development: Lesson from Guama- Bali, Indonesia. Asian Journal of Agricultural Development, Volume 11, Issue 2, 2014..

W. Windia, Penguatan Budaya Subak Melalui Pemberdayaan Petani. Jurnal Kajian Bali Volume 03, Nomor 02, 2013. Pp:137-158, 2013.

N.P.I Nopitasari, and P.Suatra, Konsep Tri Hita Karana dalam Subak. Kertha Desa, Vo.01.No. 2, July 2013. pp:1-5.

P.Sriartha, Suratman, and S.R.Giyarsih, S.R, The Effect of Regional Development on The
Sustainability of Local Irrigation System (A Case of Subak System in Badung Regency, Bali Province). Forum Geografi, Vol. 29 (1) July 2015: pp: 31 - 40, 2015.

N.Sutawan, Tri Hita Karana and Subak In Search for Alternative Concepst of Sustainable Irigated Rice Culture. Universitas Udayana: Denpasar, 2004.

W. Windia, Transformasi Sistem Irigasi Subak yang Berlandaskan Konsep Tri Hita Karana. Pustaka Bali Post, Denpasar, 2006.

A.A.G, Agung, Bali Endangered Paradise: Tri Hita Karana and the Concervation of the Island, Dissertation. Leiden University: Belanda, (online) available http://indoemirates.org/portal, 2007.

A.I.G. Wesnawa, The Change implementation of Tri Hita Karana (THK) concept in Village settlement (a Case study in Badung Bali Province). Disertation. Unpublished. UGM Yogyakarta, 2009.

J.S.Lansing, J.S, Balinese Water Temples and the Management of Irrigation. in American Antropologist No. 89, 1987.

D. Roth, and G.Sedana, Reframing Tri Hita Karana: From 'Balinese Culture' to Politics. The Asia Pacific Journal of Anthropology, 16(2), 157 - 175, 2015.

A.I.G.Wesnawa., W.Suastra, Tri Hita Karana (THK) Concept in Rural Settlements of Bali. Journal of Education and Social Sciences, Vol. 3, (Feb.).pp:75-78, 2016. 